JKKP : Jurnal Kesejahteraan Keluarga dan Pendidikan

http://doi.org/10.21009/JKKP

DOI:doi.org/10.21009/JKKP.052.08

E-ISSN : 2597-4521

\title{
PENILAIAN KETAHANAN KELUARGA TERHADAP KELUARGA GENERASI MILLENIAL DI ERA GLOBALISASI SEBAGAI SALAH SATU PONDASI KETAHANAN NASIONAL
}

\author{
Lutfi Amalia \\ Lutfiamaliaadel@gmail.com \\ Program Studi Kajian Stratejik Ketahanan Nasional, Sekolah Kajian Stratejik dan Global, \\ Universitas Indonesia
}

\begin{abstract}
Abstrak
Karakter keluarga saat ini lebih dikenal dengan keluarga generasi millennial karena lingkungan sosial keluarga di era globalisasi saat ini, cenderung menggunakan teknologi sebagai alat penunjang kegiatan sehari-hari seperti menggunakan smartphone yang terkoneksi dengan internet untuk berkomunikasi antar anggota keluarga dengan media social (WhatsApp, Line, Instagram, Facebook, dII) dan untuk mengakses informasi terbaru yang ada dari seluruh belahan dunia. Pola kehidupan keluarga yang berubah karena adanya kemudahan mengakses informasi dalam penggunaan teknologi menimbulkan tantangan hidup yang semakin berat dalam kehidupan berkeluarga. Oleh karena itu penelitian ini bertujuan untuk mengetahui penilaian ketahanan keluarga terhadap keluarga generasi millenial di era globalisasi sebagai salah satu pondasi ketahanan nasional. Metode penelitian menggunakan penelitian kuantitatif untuk mengetahui penilaian ketahanan keluarga terhadap keluarga millenial di era globalisasi. Partisipan dalam penelitian ini berjumlah 115 keluarga yang terdiri dari 47 responden suami dan 68 responden istri. Indikator ketahanan keluarga berdasarkan nilai dan fungsi keluarga dibedakan menjadi tiga kategori yaitu ketahanan fisik, ketahanan social dan ketahanan psikologis. Berdasarkan hasil penelitian ketahanan keluarga generasi millenial dinilai cukup kuat karena berada pada kisaran $67 \%$ antara $88.5 \%$. Hal tersebut dikarenakan keluarga generasi millennial masih menjalankan nilai dan fungsi keluarga yang menjadi indikator ketahanan keluarga agar dapat tercipta keharmonisan dan ketahanan dalam keluarga.
\end{abstract}

Kata kunci: ketahanan keluarga, keluarga generasi millennial

\section{THE ASSESSMENT OF FAMILY SECURITY TO THE MILLENIAL GENERATION FAMILY IN THE GLOBALIZATION ERA AS ONE OF THE NATIONAL SECURITY CONDUCT}

\begin{abstract}
Today's family character is well known as millennial family because the family social environment in globalization era tends to use technology as supporting tools for daily activities such as using internet-connected smartphones to communicate between family members with social media (WhatsApp, Line, Instagram, Facebook, etc.) and to access the latest information available from all parts of the world. Patterns of family life that change because of the ease of accessing information in the use of technology raises the challenges of life that increasingly heavily in family life. Therefore, this study aims to determine the assessment of family resilience to millennial families in the era of globalization as one of the foundations of national resilience. The research method uses quantitative research to determine the assessment of family resistance to millennial families in the era of
\end{abstract}


globalization. Participants in this study amounted to 115 families consisting of 47 husband respondents and 68 wife respondents. The indicators of family resilience based on family values and functions are divided into three categories: physical resilience, social resilience and psychological resilience. Based on the results of the research, family resilience of millennial generation is considered quite strong because it is in the range of $67 \%$ between $88.5 \%$. This is because millennial family generation is still running the value and family functions that become indicators of family resilience in order to create harmony and resilience in the family.

Keywords: family resilience, millennial generation family

\section{PENDAHULUAN}

Ketahanan nasional merupakan kondisi dinamis suatu bangsa, meliputi semua aspek kehidupan untuk tetap jaya diantara keteraturan dan perubahan yang terjadi. Latar belakang ketahanan nasional suatu bangsa terdiri dari kekuatan yang ada pada suatu bangsa dan negara untuk dapat menghadapi perubahan lingkungan dan mempertahankan kelangsungan hidup meskipun mengalami berbagai gangguan dan ancaman. Ketahanan nasional tidak hanya meliputi aspek militer dalam hal pertahanan dan keamaan. Namun juga meliputi segala aspek kehidupan yang multidisiplin seperti aspek geografi, penduduk, sumber daya alam, ideologi, politik, ekonomi, social dan budaya (Usman, 2003).

Penduduk sebagai salah satu aspek ketahanan nasional, terdiri dari beberapa individu yang tinggal menetap dalam suatu wilayah tertentu. Individu tersebut biasanya hidup bersama dan berkumpul membentuk suatu institusi yang disebut sebagai institusi keluarga. Institusi keluarga merupakan institusi pertama dan utama bagi individu untuk mendapatkan pembelajaran dalam segala hal. Oleh karena itu keluarga memiliki peranan penting untuk membentuk karakter seseorang sebelum ia dapat bersosialisasi dengan lingkungan sosialnya. Karakter seseorang dapat mencerminkan pola kehidupan suatu keluarga.

Lingkungan sosial keluarga di era globalisasi saat ini, cenderung menggunakan teknologi sebagai alat penunjang kegiatan sehari-hari. Seperti menggunakan smartphone yang terkoneksi dengan internet untuk berkomunikasi antar anggota keluarga dengan media sosial (WhatsApp, Line, Instagram, Facebook, dll) dan untuk mengakses informasi terbaru yang ada dari seluruh belahan dunia. Dengan demikian karakter dari keluarga saat ini lebih dikenal dengan Keluarga Generasi Millenial. Keluarga Generasi Millenial merupakan keluarga yang terdiri dari generasi individu yang lahir antara tahun $1977 \mathrm{~s} / \mathrm{d}$ tahun 1994. Selain itu generasi millenial memiliki kepercayaan diri, rasa toleransi dan keterbukaan yang tinggi terhadap perubahan seiring dengan adanya perkembangan teknologi (Kilber, 2014).

Pola kehidupan keluarga yang berubah karena adanya kemudahan mengakses informasi dalam penggunaan teknologi menimbulkan tantangan hidup yang semakin berat dalam kehidupan berkeluarga seperti adanya informasi dunia pornografi dan tindak kriminal yang mudah diakses dan dikhawatirkan dapat di tiru dan mempengaruhi perkembangan psikologis anggota keluarga (Rahardian, 2015). Selain itu, adanya cyberbullying juga dapat membuat anggota keluarga menjadi stress karena mendapatkan perlakuan tidak menyenangkan di media sosial sehingga dapat mempengaruhi pola interaksi dalam keluarga, serta adanya beragam aplikasi media sosial dan game online dalam keluarga juga dapat mengganggu pola interaksi dan komunikasi dalam keluarga karena masing-masing anggota keluarga hanya terfokus pada peran dirinya yang aktif untuk mengakses media sosial atau game online sehingga dapat menyebabkan salah pengertian atau salah persepsi antar anggota keluarga (Sapty, 2012). Oleh karena itu suatu keluarga perlu mempertahankan nilai dan fungsi keluarga yang menjadi indicator ketahanan suatu keluarga. Karena ketahan keluarga akan menggambarkan kualitas kepribadian dan pola perilaku anggota keluarga dalam berinteraksi dan bersosialisasi dengan masyarakat.

Jurnal Kesejahteraan Keluarga dan Pendidikan [JKKP] Vol.05 No.02

Doi.org/10.21009/JKKP.052.08 
Indikator ketahanan keluarga berdasarkan nilai dan fungsi keluarga dibedakan menjadi tiga kategori yaitu ketahanan fisik, ketahanan sosial dan ketahanan psikologis. Ketahanan fisik suatu keluarga merupakan kemampuan ekonomi yang dimiliki oleh keluarga dalam memperoleh sumber daya ekonomi dari luar sistem untuk kebutuhan dasar keluarga seperti sandang, pangan, papan, pendidikan dan kesehatan. Ketahanan social merupakan kekuatan keluarga dalam menerapkan nilai dan norma agama, pemeliharaan ikatan dan komitmen serta komunikasi antar anggota keluarga, pembagian peran, penetapan tujuan serta dorongan untuk maju yang akan menjadi kekuatan dalam menghadapi tantangan, ancaman dan masalah dalam keluarga. Sedangkan ketahanan psikologis merupakan kemampuan dari anggota keluarga untuk mengelola emosinya sehingga menghasilkan konsep dan kepribadian diri yang positif (Cholilawati, dkk., 2015).

Berdasarkan permasalahan tersebut diatas, maka peneliti tertarik untuk mengetahui penilaian ketahanan keluarga terhadap keluarga generasi millenial di era globalisasi sebagai salah satu pondasi ketahanan nasional.

\section{METODOLOGI PENELITIAN}

Metode penelitian menggunakan penelitian kuantitatif untuk mengetahui penilaian ketahanan keluarga terhadap keluarga millenial di era globalisasi. Penilaian ketahanan keluarga terbagi atas dua kategori yaitu penilaian pertanyaan positif yang dinilai berdasarkan kriteria ketahanan keluarga kuat sebesar $100 \% \mathrm{~s} / \mathrm{d}$ 75\%; kriteria ketahanan keluarga cukup kuat sebesar $74 \% \mathrm{~s} / \mathrm{d}$ 50\%; kriteria ketahanan keluarga kurang sebesar $49 \% \mathrm{~s} / \mathrm{d} 25 \%$; ketahanan keluarga tidak kuat sebesar $24 \% \mathrm{~s} / \mathrm{d} 0 \%$. Populasi penelitian ini merupakan keluarga yang berada diwilayah Jabodetabek dengan kriteria menggunakan smartphone, sudah menikah dan memiliki anak. Teknik pengambilan data pada penelitian ini menggunakan media google form yang disebar melalui media sosial seperti WhatsApp, Instagram, Facebook, Line, dan Path. Berdasarkan teknik pengambilan data tersebut, keluarga yang bersedia menjadi partisipan dalam penelitian ini berjumlah 115 keluarga atau dalam penelitian ini disebut sebagai sample penelitian yang terdiri dari 47 responden sebagai seorang suami dan 68 responden sebagai seorang istri dalam keluarga.

\section{HASIL DAN PEMBAHASAN}

Penilaian ketahanan keluarga terhadap keluarga milenial di globalisasi dikategorikan kedalam tiga bagian tema pertanyaan yaitu (1) ketahanan fisik yang terdiri dari pertanyaan tentang jenis pekerjaan suami/istri dan total pendapatan keluarga dalam satu bulan, status kepemilikan rumah, jumlah anak, pemenuhan pangan dan sandang, dan pespektif pendidikan dalam keluarga; (2) ketahanan sosial yang terdiri dari pertanyaan tentang ketersediaan waktu untuk berinteraksi dalam keluarga, penggunaan smartphone dalam keluarga, penggunaan media sosial dalam keluarga, penanaman budaya dalam keluarga; dan (3) ketahanan psikologis tentang pengelolaan emosi dalam keluarga.

Ketahanan fisik keluarga yang di klasifikasikan kedalam jenis pekerjaan pasangan suami/istri dan penghasilan dalam keluarga menunjukkan status sosial suatu keluarga. Dimana sebesar 101 responden memiliki pekerjaan tetap seperti 38 responden adalah karyawan swasta; 21 responden adalah tenaga professional; 21 responden adalah PNS/TNI/Polri; 21 responden adalah wiraswasta. Sedangkan sebesar 14 responden memiliki pekerjaan tidak tetap/tidak bekerja seperti 5 responden adalah freelance dan 9 responden adalah tidak bekerja. 


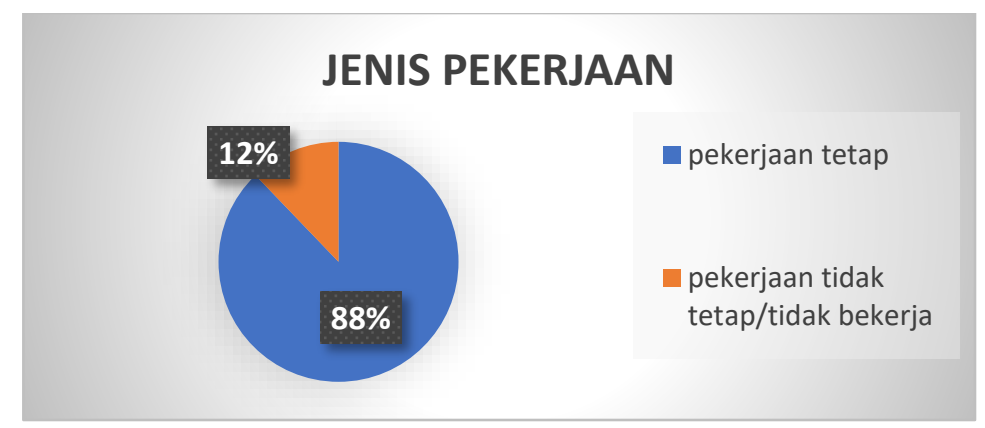

Gambar 1. Jenis Pekerjaan

Pendidikan terakhir responden yaitu sebesar 91 responden adalah memiliki pendidikan perguruan tinggi yang terdiri dari 3 responden adalah lulusan S3, 53 responden adalah lulusan $S 1,26$ responden adalah lulusan S2, 9 responden adalah lulusan D3 dan sebesar 24 responden adalah memiliki pendidikan sekolah menengah.

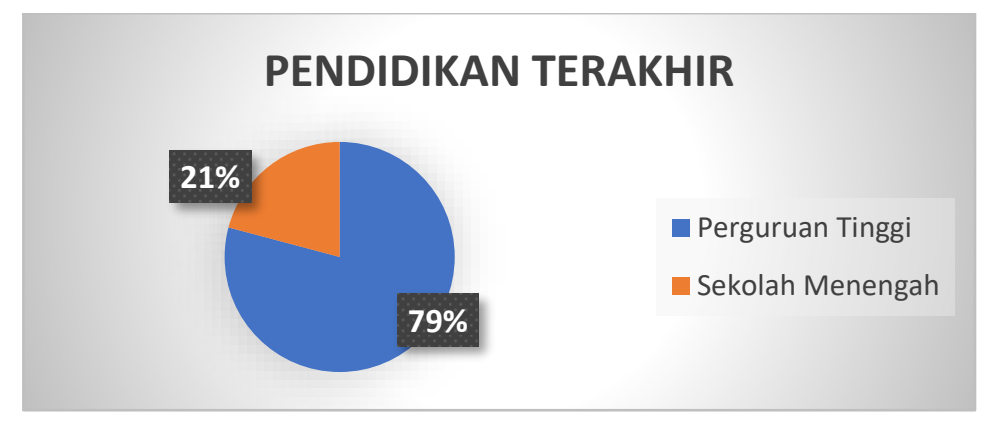

Gambar 2. Pendidikan Terakhir

Total pendapatan suatu keluarga sebesar 60 responden adalah responden berpenghasilan $>9 \mathrm{jt} / \mathrm{bulan} ; 30$ responden adalah responden berpenghasilan $6.1 \mathrm{jt} \mathrm{s} / \mathrm{d}$ 9j//bulan; 23 responden adalah responden berpenghasilan $3.1 \mathrm{jt} \mathrm{s/d} \mathrm{6j/bulan} \mathrm{dan} 2$ responden adalah responden berpenghasilan $1 \mathrm{jt}$ s/d 3jt/bulan.

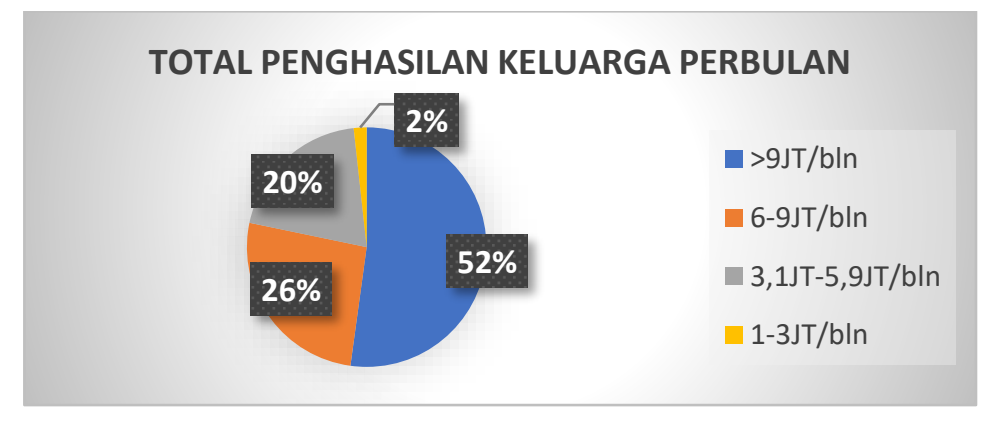

Gambar 3. Penghasilan keluarga perbulan

Berdasarkan data yang telah diperoleh, keluarga yang memiliki pasangan responden bekerja adalah sebesar 96 responden dan pasangan responden yang tidak bekerja adalah sebesar 19 responden. 


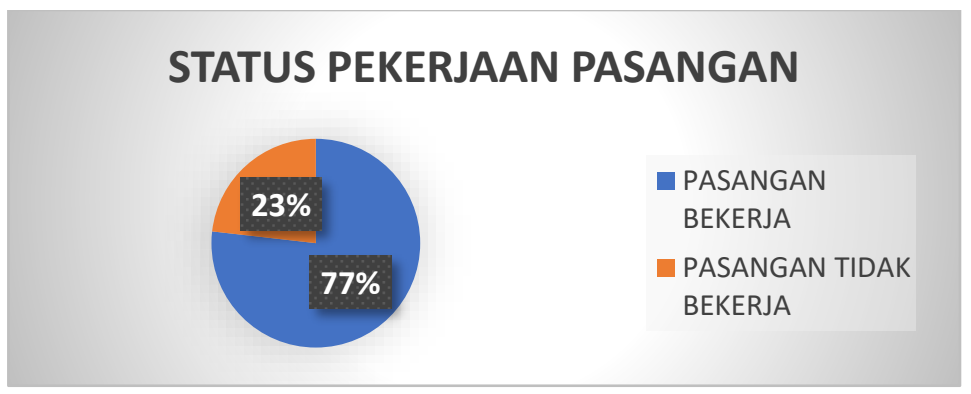

Gambar 4. Status Pekerjaan Pasangan

Status kepemilikan rumah yang dimiliki responden sebesar 76 responden adalah memiliki rumah milik sendiri dan sebesar 39 responden adalah belum memiliki rumah milik sendiri yaitu sebesar 18 responden adalah menyewa rumah dan sebesar 21 responden adalah memiliki rumah dinas/hibah.

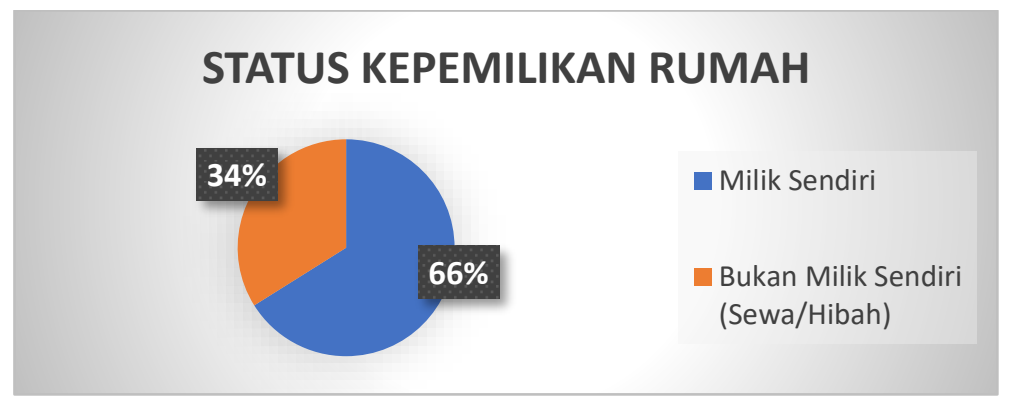

Gambar 5. Status Kepemilikan Rumah

Jumlah anak responden yaitu sebesar 44 responden adalah memiliki 1 orang anak; 36 responden adalah memiliki sebesar 2 orang anak; sebesar 10 responden adalah memiliki 3 orang anak dan sebesar 25 responden adalah memiliki $>3$ orang anak.

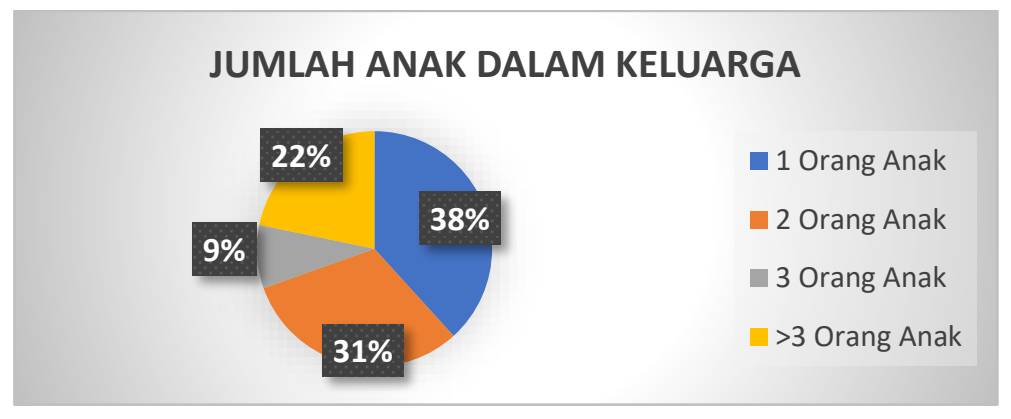

Gambar 6. Jumlah anak dalam keluarga

Pendidikan anak responden saat ini yaitu sebesar 46 responden adalah memiliki anak belum sekolah; 23 responden adalah memiliki anak bersekolah playgroup/tk; 18 responden adalah memiliki anak bersekolah tingkat sekolah dasar/SD; 16 responden adalah memiliki anak bersekolah tingkat menengah pertama dan atas/SMP\&SMA; dan 12 responden adalah memiliki anak bersekolah perguruan tinggi. 


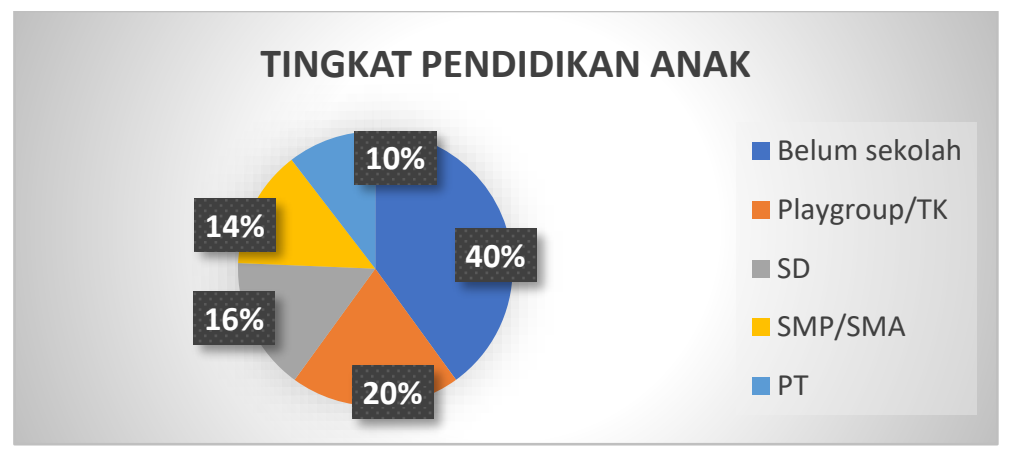

Gambar 7. Tingkat pendidikan anak

Prioritas jenis pendidikan anak bagi responden yaitu 75 responden adalah sekolah negeri; dan sebesar 40 responden adalah sekolah swasta.

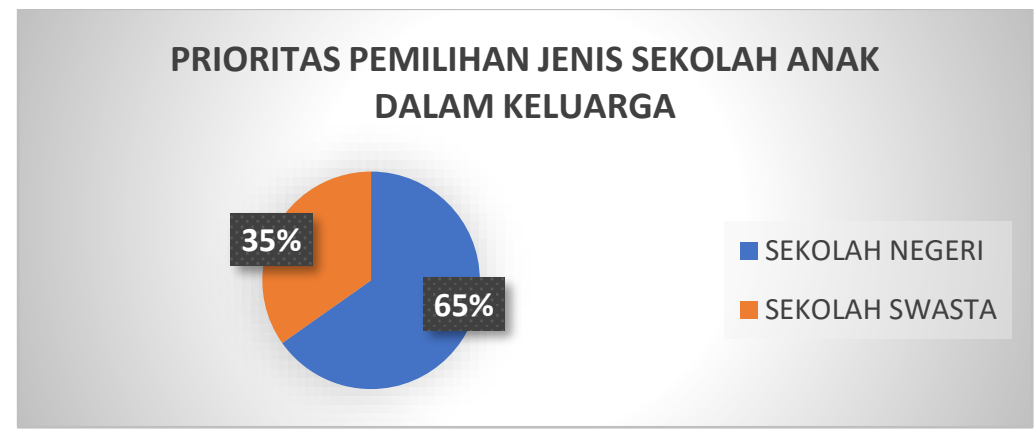

Gambar 8. Prioritas pemilihan jenis sekolah anak dalam keluarga

Dengan demikian rata-rata persentase tingkat ketahanan keluarga berdasarkan ketahanan fisik yang dinilai dari sebagian besar responden memiliki pekerjaan tetap, memiliki pasangan yang bekerja, memiliki penghasilan yang cukup untuk memenuhi kebutuhan keluarga, memiliki rumah sendiri, memiliki jumlah anak yang ideal menurut BKKBN yaitu jumlah anak tidak lebih dari 2 adalah cukup (BKKBN, 2007), dan pendidikan anak diprioritaskan pada sekolah negeri yaitu sebesar $67 \%$ dengan kriteria ketahanan keluarga cukup kuat.

Ketahanan sosial keluarga yang diklasifikan dengan ketersediaan waktu untuk berinteraksi dalam keluarga, penggunaan smartphone dalam keluarga, penggunaan media sosial dalam keluarga, dan penanaman budaya dalam keluarga.

Dimana keluarga yang menggunakan teknologi untuk menunjang kegiatan sehari-hari adalah sebesar 112 responden dan sebesar 3 keluarga adalah keluarga yang tidak menggunakan teknologi dalam menunjang kegiatan kehidupan sehari-hari. 


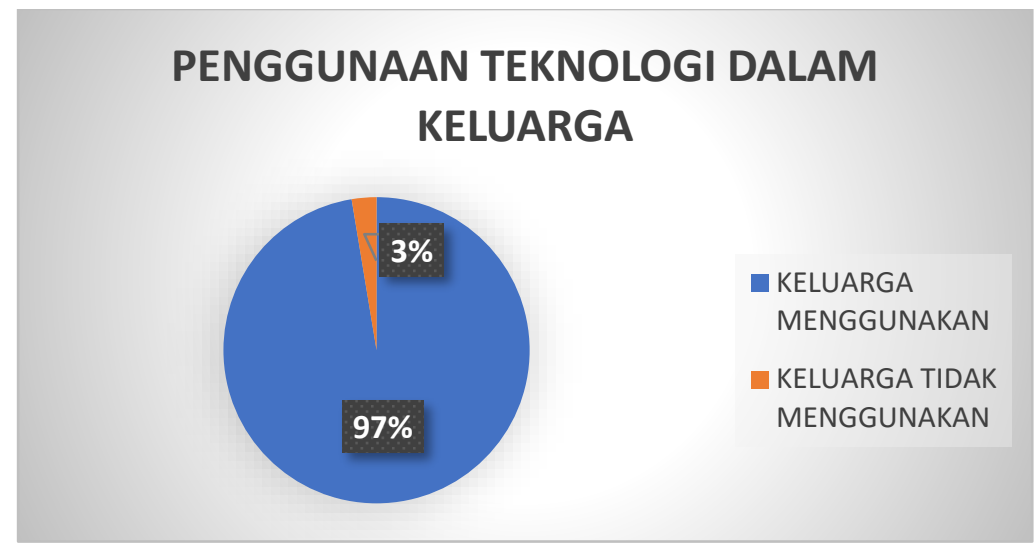

Gambar 9. Penggunaan teknologi dalam keluarga

Jumlah perangkat smartphone/tablet yang dimiliki responden yaitu sebesar 59 responden adalah menggunakan 1 buah smartphone/tablet, sebesar 42 responden adalah menggunakan 2 buah smartphone/tablet, sebesar 7 responden adalah menggunakan 3 buah smartphone/tablet dan 4 responden adalah menggunakan $>3$ buah smartphone/tablet.

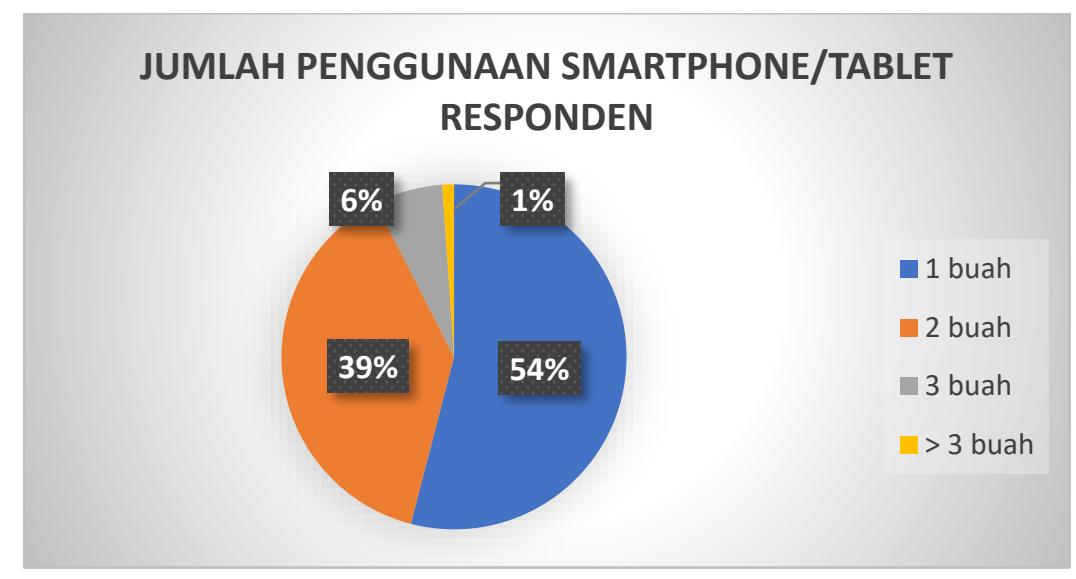

Gambar 10. Jumlah penggunaan smartphone/tablet dalam keluarga

Penggunaan smartphone bagi anak dalam keluarga yaitu sebesar 27 responden adalah memiliki anak yang mempunyai smartphone/tablet sendiri dan sebesar 88 responden adalah memiliki anak yang tidak mempunyai smartphone/tablet sendiri.

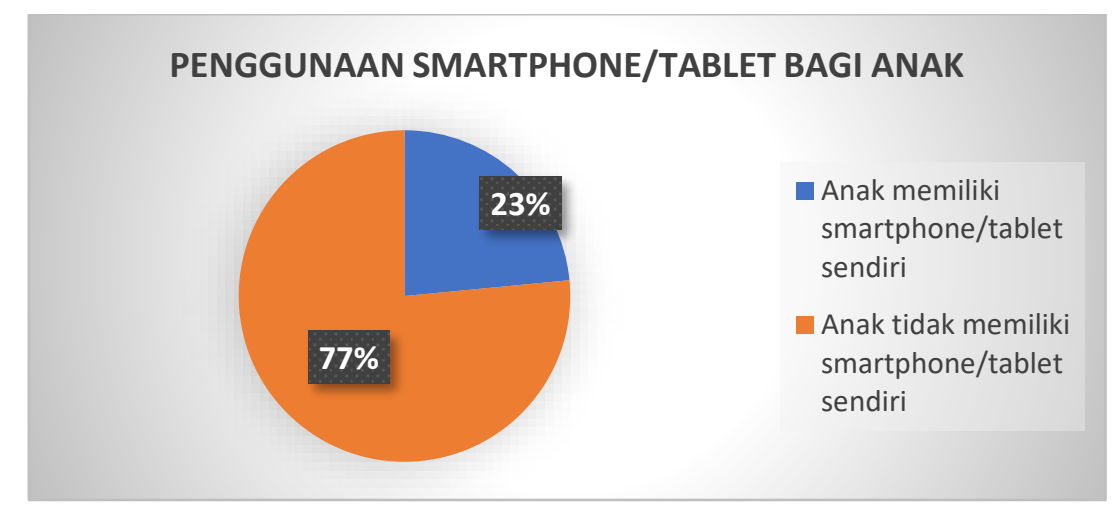

Gambar 11. Penggunaan smartphone/tablet bagi anak 
Pengawasan penggunaan smartphone/tablet bagi anak dalam keluarga yaitu sebesar 97 responden adalah mengawasi penggunaan smartphone/tablet pada anak dan sebesar 18 responden adalah tidak mengawasi penggunaan smartphone/tablet pada anak

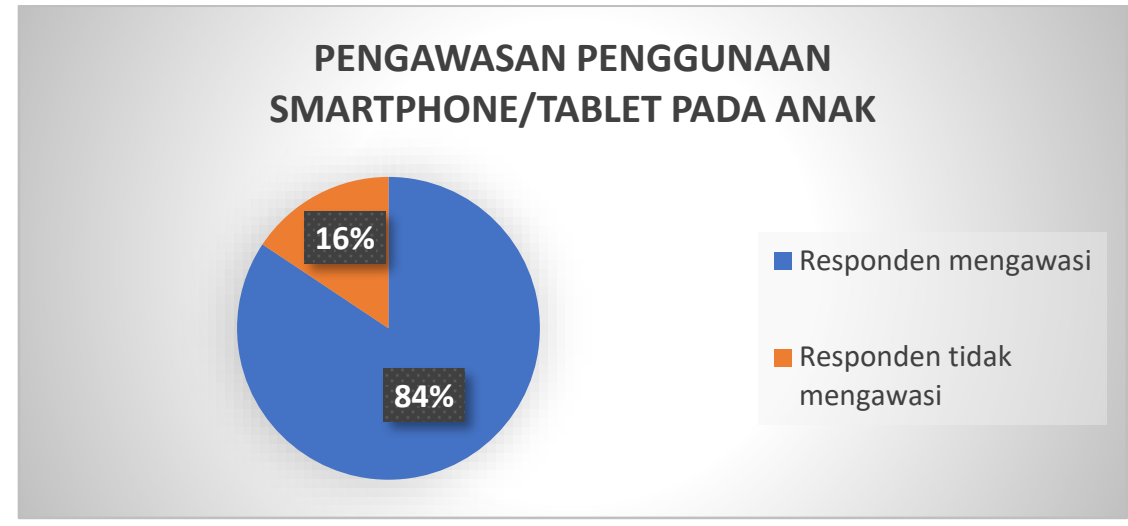

Gambar 12. Pengawasan penggunaan smartphone/tablet bagi anak

Penggunaan media sosial dalam keluarga sebagai sarana komunikasi antar keluarga yaitu sebesar 114 responden adalah keluarga yang menggunakan media sosial dan 1 responden adalah keluarga yang tidak menggunakan media social.

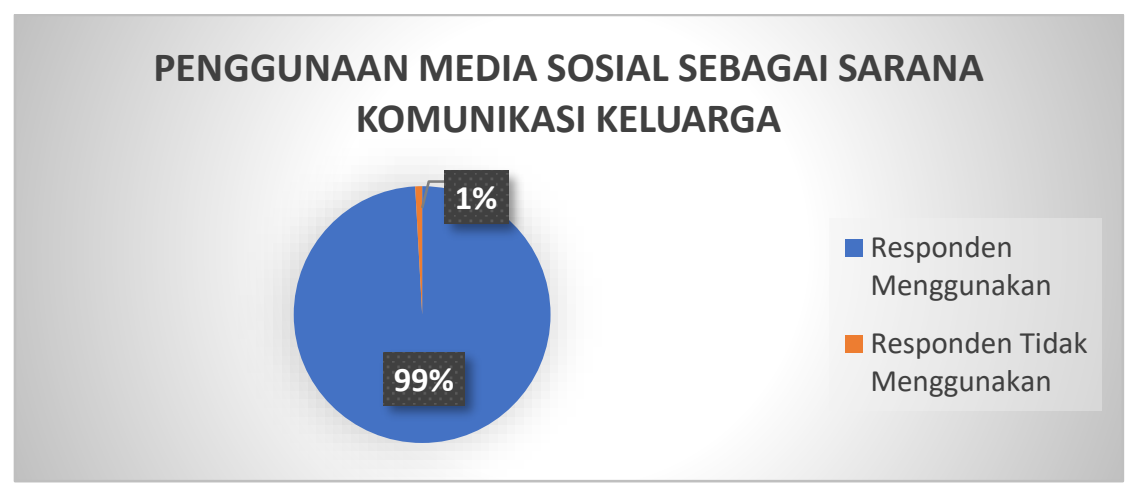

Gambar 13. Penggunaan media social sebagai sarana komunikasi keluarga

Frekuensi keluarga menggunakan media sosial sebagai sarana komunikasi antar anggota keluarga yaitu sebesar 75 responden adalah setiap waktu istirahat kerja, sebesar 23 responden adalah setiap satu jam sekali, sebesar 10 responden adalah sebesar enam jam sekali, dan sebesar 7 responden adalah tidak pernah. 


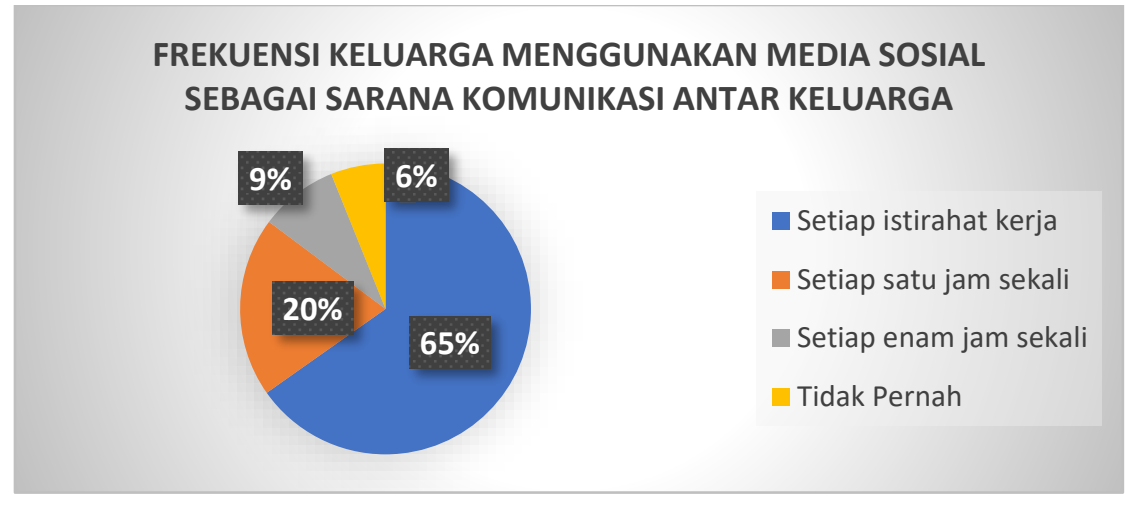

Gambar 14. Frekuensi keluarga menggunakan media social sebagai sarana komunikasi antar keluarga

Keluarga memiliki waktu khusus dengan anggota keluarga dirumah yaitu sebesar 49 responden adalah saat responden pulang kerja, sebesar 36 responden adalah saat makan malam bersama, sebesar 13 responden adalah saat makan pagi bersama, dan sebesar 7 responden adalah saat jadwal anak pulang sekolah.

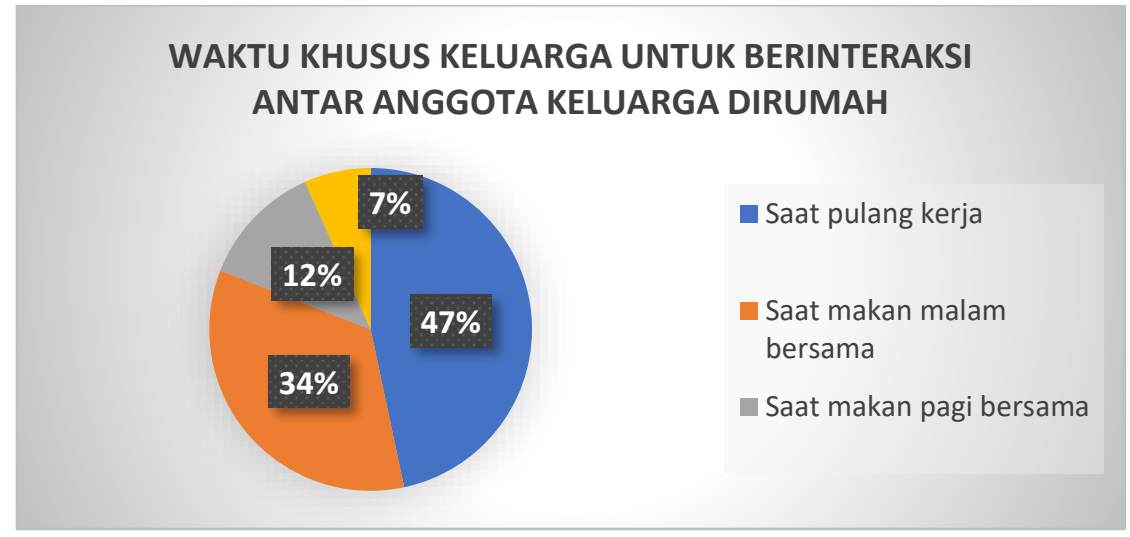

Gambar 15. Waktu khusus keluarga untuk berinteraksi antar anggota keluarga dirumah

Keluarga meluangkan waktu khusus untuk pergi jalan-jalan bersama anggota keluara yaitu sebesar 71 responden adalah meluangkan waktu seminggu sekali, sebesar 17 responden adalah meluangkan waktu >tiga minggu sekali, sebesar 14 responden adalah meluangkan waktu setiap dua minggu sekali dan sebesar 13 responden adalah meluangkan waktu setiap tiga minggu sekali. 


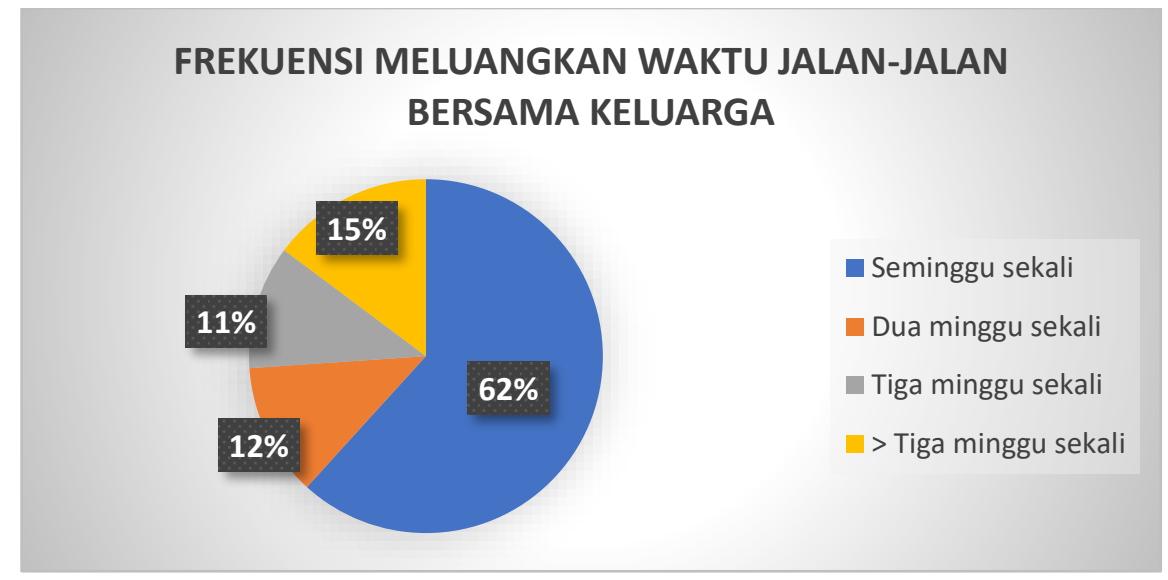

Gambar 16. Frekuensi meluangkan waktu jalan-jalan bersama keluarga

Keluarga yang dapat membedakan segala informasi dari media sosial berdasarkan berita fakta dan berita hoax/palsu yaitu sebesar 102 responden adalah dapat membedakan berita fakta dan berita hoax/palsu serta sebesar 13 responden adalah tidak dapat membedakan berita fakta dan berita hoax/palsu.

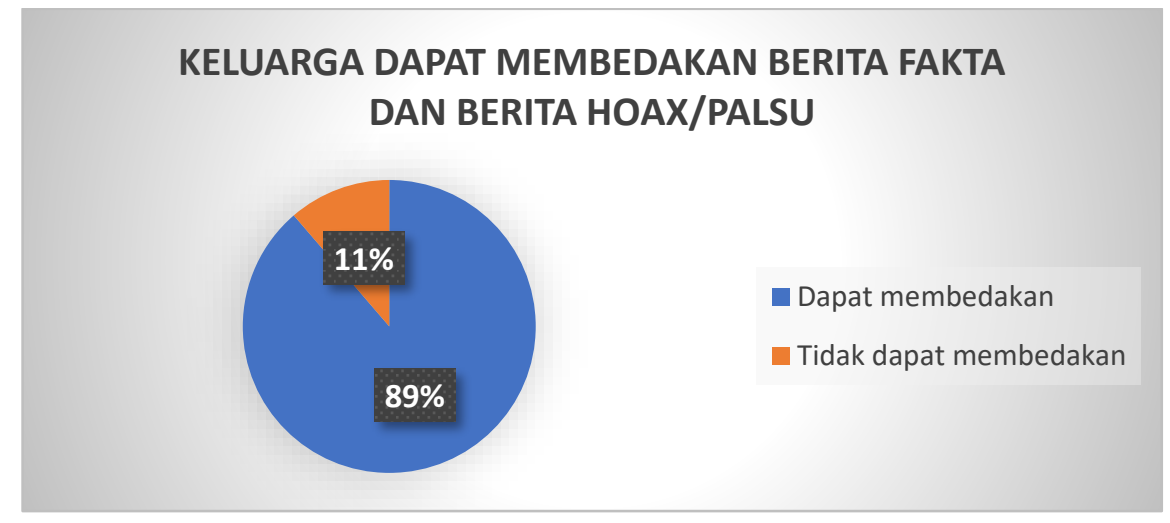

Gambar 17. Keluarga dapat membedakan berita fakta dan berita hoax/palsu

Keluarga yang menanamkan nilai dan norma yang berlaku dalam keluarga yaitu sebesar 115 responden adalah keluarga menanamkan nilai dan norma. 


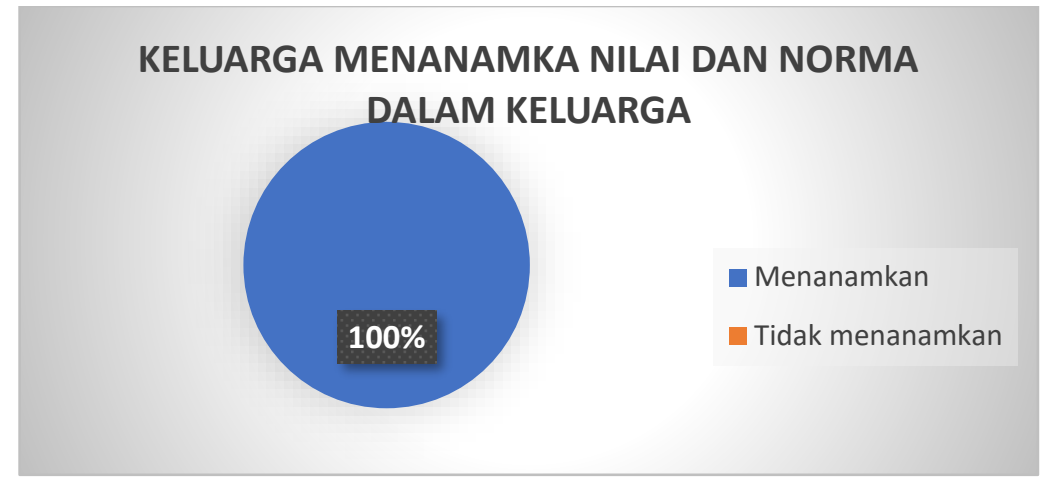

Gambar 18. Keluarga menanamkan nilai dan norma dalam keluarga

Keluarga menanamkan budaya untuk tidak menggunakan alat komunikasi pada saat berkumpul bersama keluarga yaitu sebesar 96 responden adalah menanamkan dan sebesar 19 responden tidak menanamkan.

KELUARGA MENYELESAIKAN MASALAH DALAM KELUARGA DENGAN DISKUSI

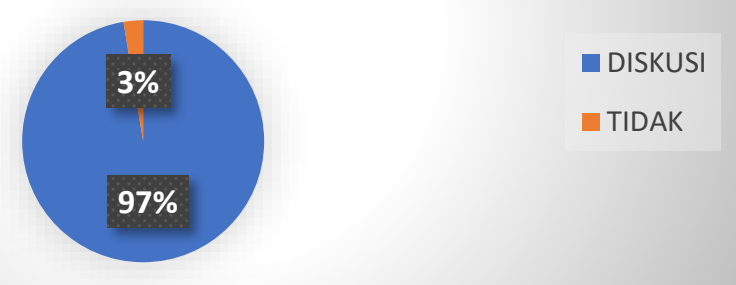

Gambar 19. Keluarga menyelesaikan masalah dalam keluarga dengan diskusi

Keluarga menyelesaikan masalah dalam keluarga dengan mendiskusikannya dengan anggota keluarga yaitu sebesar 112 responden adalah mendiskusikannya dan sebesar 3 responden adalah tidak mendiskusikannya.

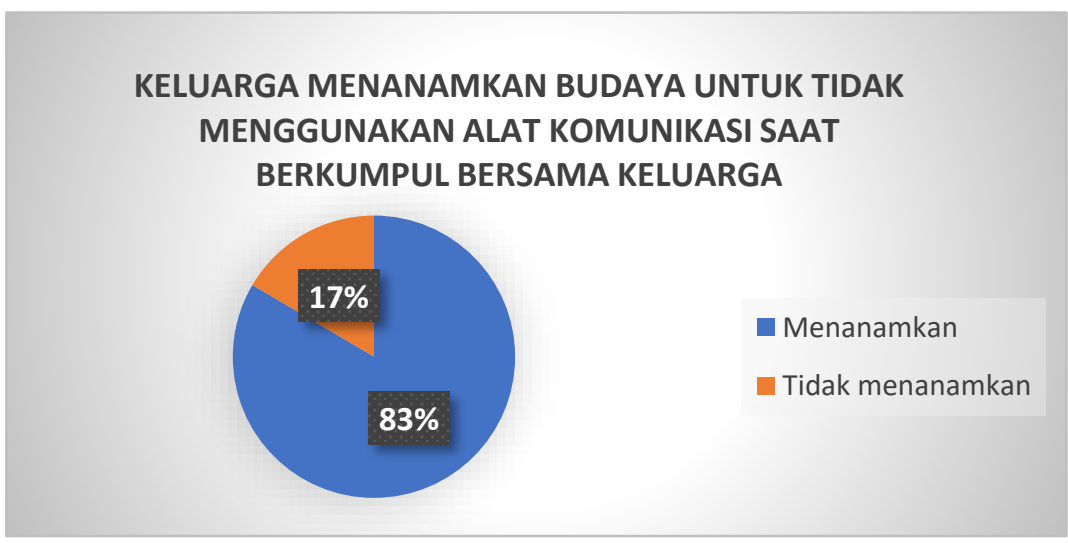

Gambar 20. Keluarga menanamkan budaya untuk tidak menggunakan alat komunikasi Menggunakan alat komunikasi saat berkumpul bersama keluarga 
Dengan demikian rata-rata persentase tingkat ketahanan sosial keluarga berdasarkan ketersediaan waktu untuk berinteraksi dalam keluarga, penggunaan smartphone dalam keluarga, penggunaan media sosial dalam keluarga, dan penanaman budaya dalam keluarga yaitu sebesar $79.5 \%$ dengan kriteria ketahanan keluarga kuat.

Ketahanan psikologis keluarga yang diklasifikasikan dalam pengelolaan emosi dalam keluarga. Dimana suami/istri sebagai orangtua dalam keluarga dapat mengelola emosi dengan baik saat ada masalah keluarga yaitu sebesar 106 responden adalah dapat mengelola emosi dengan baik dan sebesar 9 responden adalah tidak dapat mengelola emosi dengan baik.

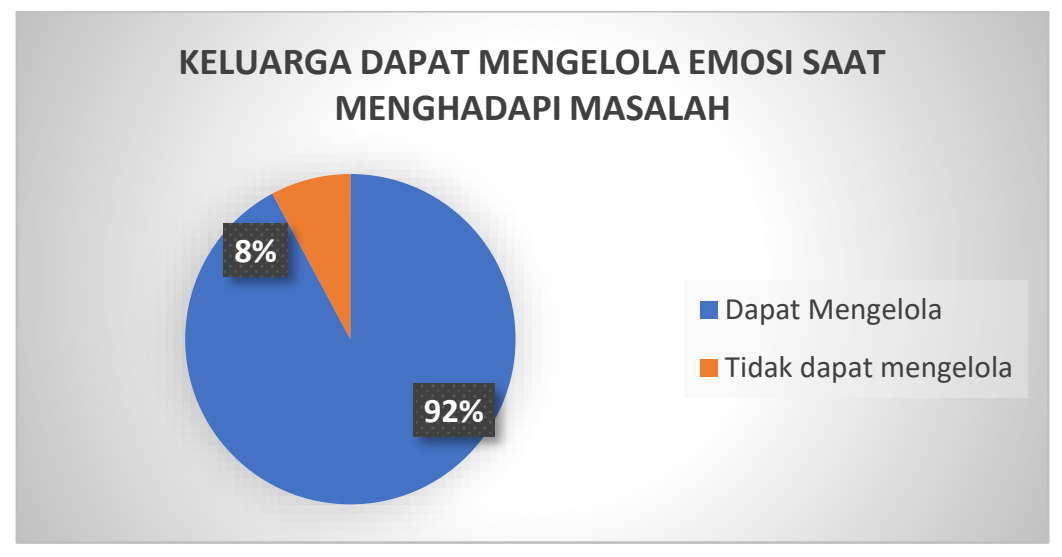

Gambar 21. Keluarga dapat mengelola emosi saat menghadapi masalah

Suami/istri sebagai orangtua dalam keluarga dapat mengendalikan emosi untuk tidak bertengkar dengan pasangan dihadapan anak-anak yaitu sebesar 106 responden adalah dapat mengendalikan emosi dan sebesar 9 responden adalah tidak dapat mengendalikan emosi.

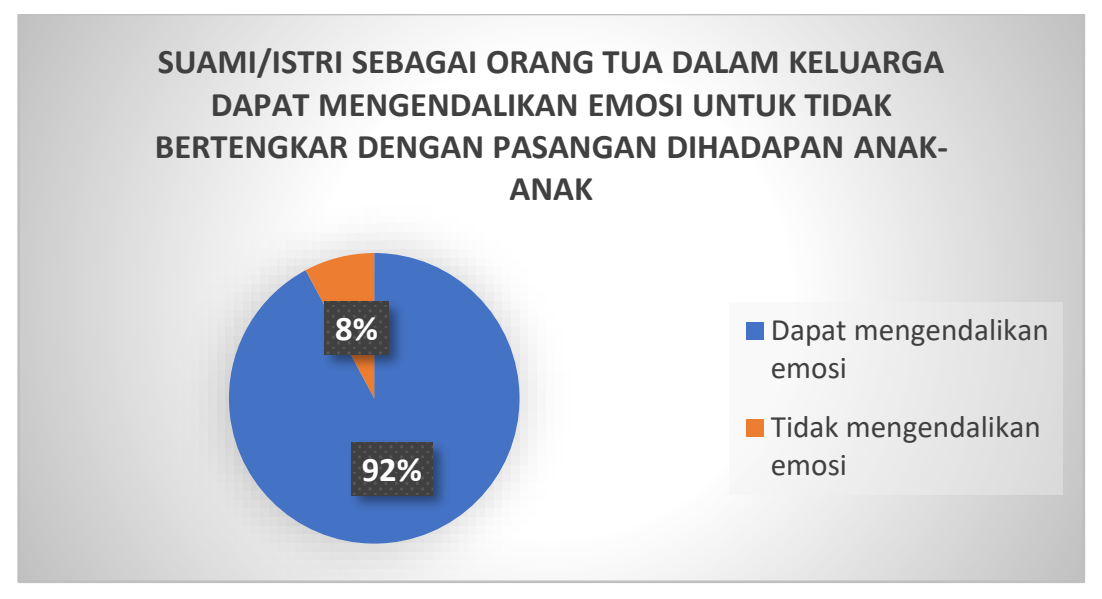

Gambar 22. Suami/istri sebagai orang tua dalam keluarga dapat mengendalikan emosi untuk tidak bertengkar dengan pasangan dihadapan anak-anak

Suami/istri sebagai orangtua dalam keluarga mampu mengelola setiap penghasilan yang dihasilkan dalam keluarga yaitu sebesar 110 responden adalah dapat mengelola dan sebesar 5 responden adalah tidak mampu mengelola. 


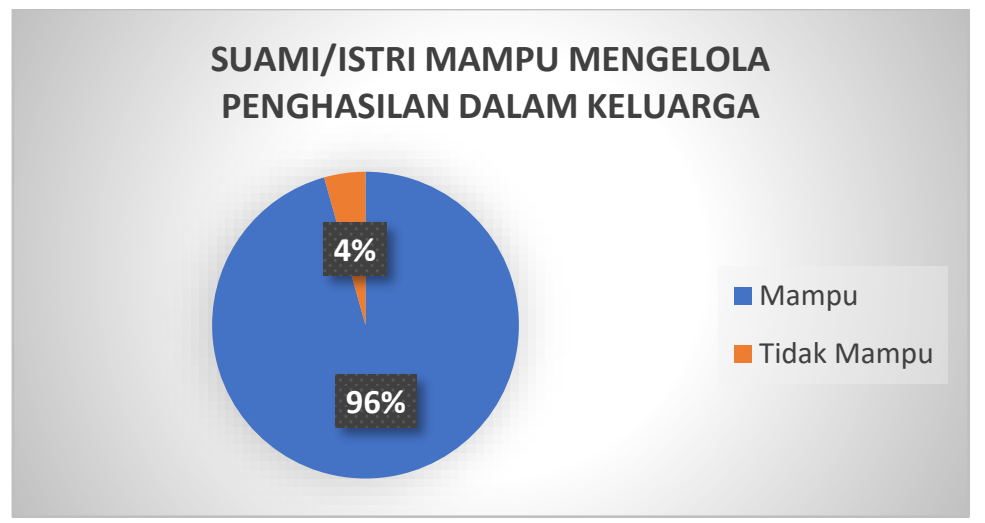

Gambar 23. Suami/istri mampu mengelola penghasilan dalam keluarga

Suami/istri sebagai orang tua merasakan stress jika keluarga kehilangan anggota keluarga/kehilangan hal yang bersifat materil dan non materil yaitu sebesar 85 responden adalah stress dan 30 responden adalah tidak stress.

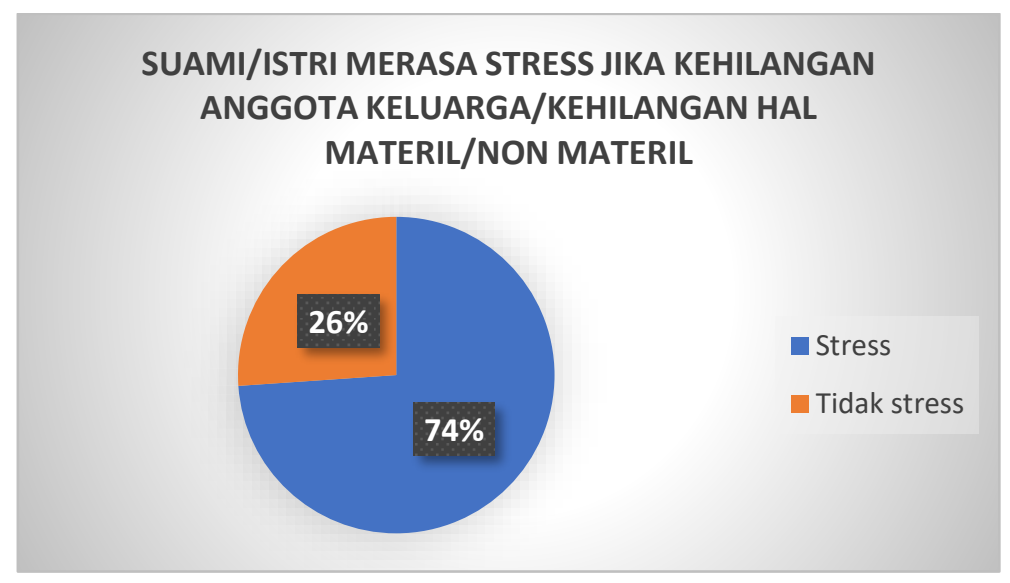

Gambar 24. Suami/istri merasa stress jika kehilangan anggota keluarga/ kehilangan hal materil/non materil

Dengan demikian rata-rata persentase tingkat ketahanan psikologis berdasarkan pengelolaan emosi dalam keluarga yaitu sebesar $88.5 \%$ dengan kriteria ketahanan keluarga kuat.

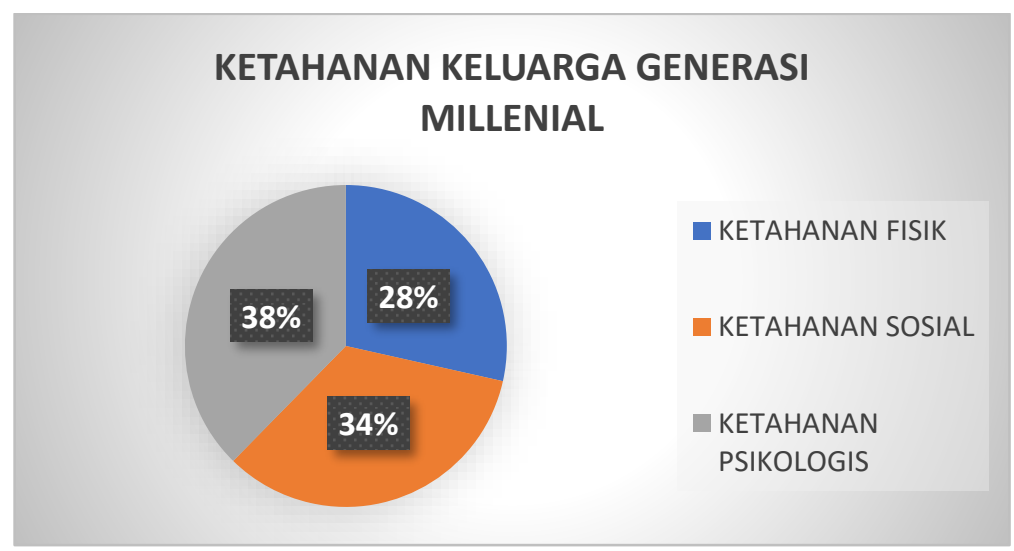

Gambar 25. Ketahanan keluarga generasi millenial 
Ketahanan keluarga millenial menunjukkan bahwa ketahanan fisik keluarga sebesar $67 \%$, ketahanan sosial keluarga sebesar $79.5 \%$

\section{KESIMPULAN}

Tantangan hidup yang semakin berat dalam kehidupan berkeluarga menjadi hal yang sangat penting bagi Keluarga Millenial untuk selalu mempertahankan ketahanan keluarga karena adanya penggunaan teknologi sebagai alat penunjang untuk kegiatan sehari-hari. Indicator ketahanan keluarga berdasarkan nilai dan fungsi keluarga dibedakan menjadi tiga kategori yaitu ketahanan fisik, ketahanan social dan ketahanan psikologis. Hasil penilaian ketahanan keluarga millenial menunjukkan bahwa ketahanan fisik keluarga sebesar $67 \%$, ketahanan sosial keluarga sebesar $79.5 \%$ dan ketahanan psikologis keluarga sebesar $88.5 \%$ dengan demikian hasil ketahanan keluarga generasi millenial dinilai cukup kuat karena berada pada kisaran $67 \%$ antara $88.5 \%$. Hal tersebut dikarenakan keluarga generasi millennial masih menjalankan nilai dan fungsi keluarga yang menjadi indikator ketahanan keluarga. Seperti keluarga generasi millennial berusaha untuk mencukupi kebutuhan keluarganya dengan cara memilih jenis pekerjaan tetap sebagai tempat sumber penghasilnya, memiliki pasangan yang juga memiliki pekerjaan sehingga mendapatkan penghasilan tambahan, berusaha mendukung program pemerintah yang di anjurkan melalui BKKBN untuk memiliki jumlah anak yang ideal tidak lebih dari dua orang anak, berkomunikasi baik dengan anggota keluarga dalam menyelesaikan masalah, meluangkan waktu khusus untuk berinteraksi dengan anggota keluarga, memiliki pengelolaan keuangan yang baik dalam keluarga serta mencoba mengendalikan emosi dengan baik didalam keluarga. Sehingga dapat tercipta keharmonisan dan ketahanan dalam keluarga.

\section{DAFTAR PUSTAKA}

BKKBN. 2007. Keluarga Berencana dan Kontrasepsi. Cetakan ke-5. Jakarta: Lembaga Pustaka Sinar Harapan.

Cholilawati., Hasanah, Uswatun dan Martiastuty, Kenty. 2015. Ketahanan Keluarga: Sebuah Tantangan di Era Global. Jakarta: Lembaga Pengembangan Pendidikan Universitas Negeri Jakarta.

Kilber, J., dkk. 2014. Seven Tips for Managing Generation Y. Journal of Management Policy and Practice. 15:4, 80-9.

Rahardian, Elfan, J. 2015. Pemanfaatan Internet dan Dampaknya Pada Pelajar SMA di Surabaya. Surabaya: Departemen IImu Informasi dan Perpustakaan Fakultas IImu Sosial dan IImu Politik Universitas Airlangga.

Sapty, Flourensia, R. 2012. Cyberbullying sebagai Dampak Negatif Penggunaan Teknologi Informasi. Yogyakarta: Universitas Atma Jaya Yogyakarta.

Usman, Wan, dkk. 2003. Daya Tahan Bangsa. Jakarta: Program Studi Pengkajian Ketahanan Nasional Universitas Indonesia. 